\title{
The Validity of Teaching Materials used Guided Inquiry Model Integrated with STEM to Train Student's Critical Thinking Skills On Thermochemistry Topic
}

\author{
Sophia Allamin*, Suyatno Sutoyo, Utiyah Azizah \\ Science Education Program \\ Post- Graduate Of Universitas Negeri Surabaya \\ Surabaya, Indonesia \\ sophiaallamin16070795028@mhs.unesa.ac.id
}

\begin{abstract}
- this research aims to produce a valid teaching material. The developed teaching materials used inquiry learning model integrated with STEM to trill students' critical thinking skills on Thermochemistry topic. The specifications of product included the syllabus, lesson plan, Student Worksheet, Student Book, the critical thinking skills test, and concept mastery test. The four indicators of critical thinking skills measured namely interpretation, analysis, inference and explanation. Model of teaching materials development used this research namely 4D model from Thiangarajan, Semmel and Semmel (1974). Validity data were obtained from the validation by experts using the validity instrument. The data obtained were analysed using Likert scale. Based on the assessment of three validators, the developed teaching materials had very valid category.
\end{abstract}

Keywords-Validity, teaching materials, inquiry, STEM, thermochemistry.

\section{INTRODUCTION}

In the 21 st century science and technology is growing so rapidly. Students are required to be able to master the various skills in order to complete globally and learn more and be proactive so they have adequate knowledge and skills. In order for chemistry education to be more focused, then after studying chemistry students are expected to gain experience in applying scientific methods, through practicum and experimentation, students perform hypothesis testing with the designing experiments through the installation of instruments, retrieval, processing, and interpretation of data, as well as passing on the experiment results orally and in writing, as well as understand the concepts, principles, laws, and theories of chemistry and mutual dependencies and its application to solve problems in daily [1].

In the learning process, perfect if students are directed to an active critical thinking, because the concept of liveliness is a pattern which is very important in constructing students ' thinking and is one of the basic learning, constructivist, that students actively construct their knowledge, not simply absorb ideas from teachers [2]. A learning process of learning requires the combined with norms of scientific approach as well as research-based learning model [3]. According to Kuhlthau et al (2007), inquiry is a model for learning that makes students discover, use various sources of information and ideas to improve understanding of problems, topics, or issues. In the 21 st century requires a learning model such as a guided inquiry learning model in science learning that is integrated with other disciplines such as technology, engineering, and mathematics such as the STEM approach.

The approach of learning STEM applying problemsolving-based learning that intentionally put scientific investigations and the application of mathematics in the context of the drafters technology as a form of problem solving. The approach of Science, Technology, Engineering, and Mathematics (STEM) is one of the scientific approaches which is a distinctive feature and has become its own strength in the existence of the 2013 Curriculum. The STEM learning approach is a problem-based learning approach that can be used to train thinking skills [4].

The chemistry learning approach using the STEM will make students don't just memorize concepts alone, but rather to how students understand and understand science concepts and their relation in daily life. Currently, the learning psychology research using STEM approach to enhance the capabilities continue to be developed. News coverage that can be used with the approach of the STEM is the thermochemistry topic at the eleventh grade of high school. The topic can be linked to the STEM approach because of the many applications in daily life that are related to the topic. In addition, thermochemistry topic can be taught using the STEM approach, namely science in finding the concept, in terms of technology can be taught by explaining various applications of technology related to the material, then through technique, students can be taught to make simple tools related to material, and mathematics is used to formulate mathematical equations related to the concepts of thermochemical topical and in terms of calculations.

However, in general, integrated Chemistry learning in the STEM approach to train critical thinking skills is still rare. Therefore, the researcher will develop a Chemistry learning tool using the STEM integrated inquiry model by using thermochemical materials to train critical thinking skills of 11 th grade high school students. 


\section{METHODS}

This research is a type of development research due to developing teaching material consisting of syllabus, lesson plan, Student Worksheets, Student Textbooks, critical thinking tests, and concept mastery tests. The learning device development model in this study uses the 4D model from Thiangarajan, et al. [5]. The 4D development model consists of 4 stages, namely (1) define, (2) design, (3) develop, and (4) deseminate. In this study only limited to the stage of development and trial only, then the fourth stage is disseminate not done.

At the define stage, the thing that is done is to define and define the learning conditions that include curriculum analysis used, then to analyze the students, analyze the concept of the material, analyze the assignments and continue the formulation of learning objectives. In the design stage, the thing that is done is the initial design of the teaching material that will be developed, namely the preparation of questions or critical thinking tests, and concept mastery tests, the selection of media in the learning process, then the selection of learning device formats developed which consist of lesson plan, Student Textbooks, Student worksheets and Assessment Instruments for Critical Thinking Skills Tests and concept mastery tests. The result of selecting the learning device format is called the initial design of the learning device called draft I. Furthermore, this draft I will be reviewed by the supervisor to be given advice and improvement.

In the develop phase, the teaching material developed will experience a revision process into draft II. This Draft II will be validated by the chemistry lecturers and teachers of chemistry. The purpose of validation is to generate valid learning device that has been validated and revised based on the input of experts so worthy a limited trial and tested extensively. Data from the learning device validation results are analyzed quantitatively. Based on the results of the average value of the validator is used to determine the quality of the learning device. The results of the validity data were analyzed using quantitative descriptive analysis by calculating the average value given by the validator $(\mathrm{P})$. This score is then described qualitatively by being interpreted according to the criteria in Table 1[6].

TABLE I. LEARNING DEVICE VALIDATION SCORE

\begin{tabular}{|c|c|c|}
\hline Score interval & Category & Explanation \\
\hline $\mathbf{3 . 6 0} \leq \mathbf{V} \leq \mathbf{4 . 0}$ & Very valid & $\begin{array}{c}\text { Can be used without } \\
\text { revision }\end{array}$ \\
\hline $\mathbf{2 . 6 0} \leq \mathbf{V} \leq \mathbf{3 . 5 9}$ & Valid & $\begin{array}{c}\text { Can be used with a few } \\
\text { revision }\end{array}$ \\
\hline $\mathbf{1 . 6 0} \leq \mathbf{V} \leq \mathbf{2 . 5 9}$ & Less valid & $\begin{array}{c}\text { Can be used with many } \\
\text { revisions }\end{array}$ \\
\hline $\mathbf{1 . 0 0} \leq \mathbf{V} \leq \mathbf{1 . 5 9}$ & Invalid & $\begin{array}{c}\text { Not yet in use and } \\
\text { requires consultation }\end{array}$ \\
\hline
\end{tabular}

The valuation agreement is calculated based on the similarity of values given by three validators with the formula:

Percentage of Agreement $=\left(1-\left[\frac{A-E}{A+E}\right]\right) \times 100 \%$

Information:

$\mathrm{A}=$ Highest score given by the assessor

$\mathrm{B}=$ Lowest score given by the assessor
Based on Table 1 above it can be seen that a learning device is said to be valid if it gets a score at an interval 2.60 $\leq \mathrm{V} \leq 3.59$ and is said to be very valid if it gets a score at intervals $3.60 \leq \mathrm{V} \leq 4.0$. Then an instrument is said to get an agreement if the percentage of agreement obtained is $\geq 75 \%$ [7]. Based on the criteria in Table 2, the teaching material developed in this study are said to be valid to be used in the learning process if they get a score of $\geq 2.6$ which meets the minimum valid criteria. Furthermore, if a learning device that is developed gets a category of less valid or invalid, then the revision is done, then the validation process is carried out again.

\section{RESULT AND DISCUSSION}

\section{A. Results}

Validation of learning devices developed includes syllabus validation, validation of lesson plan, validation of Student worksheets, validation of Student Textbooks, validation of critical thinking skills test, and validation of concept mastery tests. The teaching material developed in this study are said to be valid for use in the learning process when obtaining a minimum score of $\geq 2.66$.

1) Analysis of syllabus validation results: The results of the validation by three validators of the thermochemistry topic syllabus that writes aspects of educational unit identity, material identity, time allocation, suitability of the syllabus with the curriculum, suitability of indicators with basic competencies and suitability of assessment instruments had been analyzed and expressed as a whole is 3.80. This means that the developed syllabus in very valid category and could be used as a reference for developing syllabus, lesson plan, student worksheets, student books, critical thinking skills test. and concept mastery test with minor revisions.

2) Analysis of lesson plan validation results: The lesson plan consists of three meetings that were based on STEM integrated. The provision of writing KD refers to Permendikbud 24 Tahun 2016. Components in lesson plan included school identity, subject, class/semester, subject matter, time allocation, KI, KD, Indicator of Competency Achievement, purpose lessons learned, material summary points, learning method, media and materials, learning resources, learning steps, assessment and appraisal appendices[8]. The validation results of the three validators can be seen in the following table.

TABLE II. VALIDATION RESULT FORM LESSON PLAN

\begin{tabular}{|c|c|c|}
\hline Aspect & Average score & Category \\
\hline RPP format & 4.00 & Very valid \\
\hline Learning objectives & 3.67 & Very valid \\
\hline Learning materials & 3.33 & Valid \\
\hline $\begin{array}{c}\text { Learning models and } \\
\text { methods }\end{array}$ & 4.00 & Very valid \\
\hline $\begin{array}{c}\text { Facilities and learning } \\
\text { resources }\end{array}$ & 3.67 & Very valid \\
\hline Learning step & 3.85 & Very valid \\
\hline Evaluation & 3.33 & Valid \\
\hline Language & 3.56 & Very valid \\
\hline
\end{tabular}

Based on Table 2 the results in lesson plan validation from three validators obtained an average score of 3.69. This means that the lesson plan compiled by researchers was 
very valid category and could be used as a learning tool. So, it could be said that the developed RPP could be used as a learning guide in the classroom with little revision.

3) Analysis of student worksheet validation results: Student worksheet developed was a student worksheet learning integrated STEM used for three times. The first meeting discussed the exothermic and endothermic reactions, the second meeting discussed the reaction heat, and the third meeting discussed the determination of reaction enthalpy. Each student worksheet contains components such as title, $\mathrm{KD}$, Activity Objectives, activity steps according to the syntax of guided inquiry learning models, and bibliography[9]. Each student worksheet begins with the initial motivations to bring up phenomena related to the material being studied. Each worksheet was equipped with grouping of students into study groups, group learning and work guidance which contains guidance on formulating problems, materials used for activities, steps of activities carried out, observation tables, data analysis, conclusions, guidance on making a simple technology according to the topic taught. The three STEM integrated worksheets were equipped with answer keys that make it easier for teachers to manage learning. The validation results of the three validators can be seen in the following table.

TABLE III. VALIDATION RESULT FORM STUDENT WORKSHEET

\begin{tabular}{|l|c|c|}
\hline \multicolumn{1}{|c|}{ Aspect } & Average score & Category \\
\hline Student worksheet format & 3.78 & Very valid \\
\hline Language & 3.57 & Very valid \\
\hline $\begin{array}{l}\text { The contents of the Student } \\
\text { worksheet }\end{array}$ & 3.63 & Very valid \\
\hline
\end{tabular}

Based on Table 3 the results of the validation of three validators obtained an average score of 3.63. This means that the student worksheet compiled by researchers was categorized into very valid categories and can be used as a learning tool. So, it can be said that the developed student worksheet could be used as STEM integrated learning media to train students' critical thinking skills.

4) Analysis of student textbook validation results: Student Textbooks compiled by researchers include Thermochemistry topic. This textbook consists of learning objectives, concept maps, and study of Thermochemistry topic, pictures and illustrations related to the material, practice questions, glossarium, and bibliography. The average results of the validity of the Student Textbook validation are presented in Table 4.

\section{TABLE IV. VALIDATION RESULT FORM STUDENT} TEXTBOOK

\begin{tabular}{|l|c|c|}
\hline \multicolumn{1}{|c|}{ Aspect } & Average score & Category \\
\hline Content & 3.46 & Valid \\
\hline Language & 3.53 & Valid \\
\hline presentation & 3.60 & Very valid \\
\hline
\end{tabular}

Based on Table 4 the results of the validation of three validators obtained an average score of 3.53. This means that student textbooks compiled by researchers were categorized into valid categories and could be used as teaching material. So, it can be said that student textbooks developed could be used as STEM integrated learning media to train students' critical thinking skills.

5) Analysis of critical thinking skill test validation results: Critical thinking skills test developed in the form of four questions essay test. This question developed refers to four indicators of critical thinking skills, namely interpretation, analysis, inference, and explanation [10]. Before validation is carried out, the teaching material developed are first reviewed by the supervisor to get suggestions for improvement. The teaching material develop were validated by three validators namely Chemistry lecturers, and Chemistry teachers. Validated aspects of critical thinking skills tests include content, language and writing components. The results of the validation of critical thinking skills tests were presented in Table 5.

\section{TABLE V. VALIDATION RESULT FORM CRTICAL THINKING} SKILL TEST

\begin{tabular}{|c|c|c|}
\hline Aspect & Average score & Category \\
\hline Content & 3.60 & Very valid \\
\hline Writing and Language & 3.50 & Valid \\
\hline
\end{tabular}

Table 5 describes the validation results of critical thinking skills test instruments. Of the three aspects assessed, the average score obtained is 3.55 with very valid criteria. That is, the critical thinking skills test instrument in the form of 4-item essay questions could be used to determine the extent of students' critical thinking skills (pre-test) and also used to assess the improvement of critical thinking skills after learning using developed devices (post-test).

6) Analysis of concept mastery test validation results: The concept mastery test developed in the form of a multiple choice test of thirty-one questions was tested on eleventh grade students on MIA. Aspects that were validated in cognitive domain tests include content, language, and writing components. The results of the validation of cognitive domain tests are presented in Table 6.

\section{TABLE VI. VALIDATION RESULT FORM CONCEPT MASTERY} TEST

\begin{tabular}{|c|c|c|}
\hline Aspect & Average score & Category \\
\hline Content & 3.60 & Very valid \\
\hline Writing and Language & 3.50 & Valid \\
\hline
\end{tabular}

Table 6 describes the validation results of critical thinking skills test instruments. Of the three aspects assessed, the average score obtained was 3.89 with very valid criteria. That is, the concept mastery test instrument in the form of multiple choice questions as many as 31 items can be used to determine the extent to which students' mastery of the concept after learning using a developed device.

\section{B. Discussion}

Validation of STEM's integrated chemistry learning device to train students' critical thinking skills has gained very valid results and can be tested limited. The learning model used is a guided inquiry model. According to Kuhlthau et al (2007) that guided inquiry can help students develop research competencies, knowledge, can motivate students and can train social skills [11]. In this guided inquiry learning model, the teacher gives instructions to students as needed. These instructions can be in the form of 
questions that guide students to be able to find their own direction and actions that must be done to solve the problem given by the teacher.

Eggen \& Kauchak explained that the inquiry model was designed to help students gain an in-depth understanding of the scientific method while developing critical thinking, self-regulation, and their understanding of specific topics [12]. Students are expected to find meaning in the entire learning process. The meaning that can be taken is the association of thermochemical material with daily life / STEM. STEM is integrated between science, technology, engineering and mathematics to develop students' creativity through the process of solving problems in everyday life [13]. Chemistry learning that is able to bridge the combination of problem solving in everyday life with thermochemical material will be able to streamline the learning process.

Guided inquiry learning model integrated with STEM is learning that can be used by teachers to train students' critical thinking skills. This is because it involves students in learning that guides active students and can build their own knowledge. Guided inquiry learning model integrated with STEM combines the four disciplines into 6 phases of guided inquiry that have the same goals as the 2013 curriculum. Before doing the research trial, certainly the chemical learning developed devices need to be validated before by experts. Validated learning tools include syllabus, lesson plans, student worksheets, student textbooks, technical thinking skills tests, concept mastery tests. Device validation was carried out by chemistry lecturers and chemistry teacher, this was done so that the learning tools developed were suitable for research.

The syllabus is a learning tool that contains subject identity, school identity, core competencies, basic competencies, subject matter, learning, assessment, time allocation, learning resources. The syllabus is used as a reference in developing learning implementation plans. In the preparation of this syllabus there are components of the syllabus that are developed, namely: identity, learning activities, assessment, and learning resources.

Lesson plan is a plan of learning activities for one or more meetings. Lesson plan is developed from a syllabus to direct student learning activities in an effort to achieve Basic Competencies (KD). The material prepared in the RPP developed with the STEM integrated inquiry model is Thermochemistry. The syntax of guided inquiry model includes 6 phases, namely: 1) Initiation phase, problem orientation and explaining the inquiry process, 2) the selection phase, looking for information, as students sit with their groups to find and collect data about the problems posed by teachers from various sources, 3) the formulation phase, students are guided by the teacher to formulate hypotheses and variables that are relevant to the problem and select the hypothesis that is the priority of the investigation, 4) collection phase, students test and prove the hypothesis by experimenting and analyzing the results of their observations on the experiments / problems that have been presented by the teacher, at this stage students also design a technology based on the principles of thermochemical material. Students in this phase process and analyze experimental results data 5) presentation phase, Students formulate and draw conclusions from the results of the experiment with the guidance of the teacher, presenting the final report. Each group member from each group comments to the presentation group 6) Assessment phase, students evaluate the learning process that has been done to obtain information about the achievement of learning objectives.

One of the most important components in thermochemical learning is the availability of Student Textbooks. In this thermochemical learning, student textbooks have been developed with reference to procedures, phenomena with problems discussed in the topic, fostering curiosity, the level of development of students' thinking, have been declared suitable as Thermochemical textbooks and suitable for use in thermochemical learning.

The student worksheet serves as a student guide that is used to conduct investigation or problem solving activities, helping students in developing concepts and subject matter through discovery activities, training students to find a new concept by using scientific methods [14]. Student worksheets can also be used to train critical thinking skills by referring to scientific activities such as formulating problems, making research hypotheses, making research variables, analyzing data from activities or observations and drawing conclusions. Thermochemical student worksheets have been developed mainly referring to natural phenomena in the surrounding environment, containing the sequence of steps and learning procedures by following the stages of guided inquiry models, using the STEM approach, fostering curiosity, training critical thinking skills. Thus, the worksheets of the Thermochemistry students have been considered to facilitate students in learning Chemistry to train critical thinking skills.

Critical thinking skills test contains 4 items of essay items. This test is adjusted to four indicators of critical thinking skills. This test is equipped with a rubric or answer grid to facilitate the teacher in the assessment process. The question of critical thinking skills developed refers to Facione. The critical thinking indicator used in the question consists of 4 indicators, namely, interpretation, analysis, inference, explanation. The results of the validation of the critical thinking skills test have been categorized as very valid and should be tested in the classroom learning process.

The last development of learning tools is the concept understanding test. Concept mastery test was developed to measure students' mastery of the material taught by the teacher or learned by students. A good concept mastery test must be able to measure students' abilities in understanding the material being taught [15]. The results of the validation of the mastery test of the concept have been declared to be very valid and must be tested for the learning process in the classroom.

\section{CONCLUSIONS}

Based on the results of the study and discussion, it can be concluded that the teaching materials of STEM integrated inquiry model to train critical thinking skills developed which includes syllabus, lesson plans, student worksheets, student textbooks, critical thinking skills tests, and concept mastery tests are declared very valid, so they could be used in the thermochemistry learning process. 


\section{ACKNOWLEDGMENT}

We thank Mr. Bambang Sugiarto and Mrs Bertha Yonata from Department of Chemistry, Universitas Negeri Surabaya, for help in validation of the teaching materials

\section{REFERENCES}

[1] Mustaji. Pengembangan Kemampuan Berpikir Kritis dan Kreatif dalam Pembelajaran. Surabaya: Universitas Negeri Surabaya, 2013

[2] F. C. Lunenburg. "Critical thinking and constructivism techniques for improving student achievement". National Forum of Teacher Education Journal, 2011, Vol. 21, No. 3, pp: 1-9.

[3] Mendikbud. Permendikbud No 22 Tahun 2016 tentang standar Proses Pendidikan Dasar dan Menengah. Jakarta: Mendikbud, 2016.

[4] S. Z. Beers. 1st Century Skills : Preparing Students For Their Future. An ASCD Action Tool, 2011.

[5] Ibrahim, M. Model Pembelajaran Inovatif IPA Melalui Pemaknaan. Unesa. Surabaya: Tim Balitbang Diknas, 2008.

[6] Riduwan. Skala Pengukuran Variabel-Variabel Penelitian. Bandung: Alfabeta, 2010.
[7] Borich, G.D. Observation Skill for Effective Teaching. $2^{\text {nd }}$ ed. New York: Macmillan Publishing Company, 1994.

[8] Permendikbud RI Nomor 103 Tentang Pembelajaran Pada Pendidikan Dasar dan Pendidikan Menengah. Jakarta: Depdiknas, 2014.

[9] Departemen Pendidikan Nasional. Panduan Pengembangan Bahan Ajar, Jakarta: Depdiknas, 2008.

[10] Facione, P.A. Critical Thinking : What It is and Why It Count. Measured Reasons. Millbrae, CA: The California Academic Press, 2013.

[11] Carol C. Kuhlthau. Ann K. Caspari., \& L. K. Maniotes. Guided Inquiry Learning in the 21st Century. London:Libraries, 2007.

[12] P.D. Eggen, and D.P. Kauchack. Strategy for Teachers: Teaching Content and Thinking Skills. Boston: Allyn and Bacon, 1996.

[13] Winarni, Z. dkk. STEM: Apa, Mengapa, dan Bagaiamana. Prosiding Seminar Nasional Pendidikan IPA Pascasarjana UM, 2016, Vol.1, pp: 976-984.

[14] Ahmadi, H. R. Telaah Kurikulum Fisika SMU (Model Pembelajaran Konsep dengan LKS), Surabaya: University Press, 1996.

[15] Purwanto. Evaluasi Hasil Belajar. Yogyakarta: Pustaka Pelajar, 2010. 